\title{
A study on Reverse Merger in India: Tax Implications
}

\author{
Mohd Aadil Khan, Assim Hasan \\ Assistant Professor, Institute of Technology \& Science,Mohan Nagar,Ghaziabad \\ Student Researcher ,k.i.e.t group of Institutions, Ghaziabad,
}

\begin{abstract}
Corporate restructuring is defined as a fundamental change in direction and strategy for an organization, which affect the way in which the organization is structured. Corporate restructuring brings the substantial changes in top and bottom level of an organization. The pace of corporate restructuring has increased since the beginning of liberalization era. Due to enhanced competition, FDIs, globalization, free flow of capital across the countries and breaking of trade barriers Mergers and Acquisitions have become more popular in recent times. Mounting pressure to seek Alternative Avenue of growth is turning corporate structuring into mainstream corporate issue. Integration decisions are often justified by the synergies they create. MERGER is one of the most common forms of non-organic corporate restructure. Corporate structuring was the preferential path adopted by companies to increase their profits and streamline their functioning in the competitive scenario. The concept of reverse merger has emerged as a magical talisman for corporate restructuring and hence saving corporate tax. This paper is an attempt to analyze the prevalence of reverse merger in India and its implications on corporate tax.
\end{abstract}

Key words: Taxation, Merger, Reverse Merger, corporate Restructuring

\section{Introduction:}

In today's dynamic economic scenario the corporate sector of the world is changing at a mind boggling pace. Mergers and demergers are the paths adopted by majority of companies in the contemporary era to enhance their profits and to streamline their functioning. MERGER is one of the most common forms of non organic corporate restructure programmes that is adopted by the corporate world so as to achieve growth for the company as a whole. In the strict economic sense of the word it would mean the "union of two or more commercial interests, corporations, undertakings, bodies or any other entities. In the corporate business it means, fusion of two or more corporations by the transfer of all property to a single corporation."

Generally, a company with the track record of having a less profit earning or loss making amalgamates with a viable company to have benefits of economies of scale of production and marketing network etc. As a consequence of this merger the profit earning company survives and the loss making company extinguishes its existence. But, in many cases, the sick company's survival becomes more important for many strategic reasons and to conserve community interest. This type of non-routine merger is called Reverse Merger.

\section{Concept of reverse merger}

Reverse Merger is defined in two ways firstly where a holding company merges with a subsidiary or investee company and secondly where a profit making company is merged with the loss making company.

The term Reverse merger has not been defined specifically under any of the statutes however; High Court has discussed three tests for reverse merger-

i) Assets of Transferor Company being greater than Transferee Company.

ii) Equity capital to be issued by the transferee company pursuant to the acquisition exceeds its original issued capital.

iii) The change of control in the transferee company clearly indicated that the present arrangement was an arrangement, which was a typical illustration of take over by reverse bid.

Court held that prima facie the scheme of merging a prosperous unit with a sick unit couldn't be said to be offending the provisions of section 72 A of the Income Tax Act, 1961 since the object underlying this provision was to facilitate the merger of sick industrial unit with a sound one.

This merger is generally adopted for two main reasons-

i) It is an alternative method for private companies to become public, without undergoing the long and convoluted process of traditional IPO. In this process a private company acquires a public entity by owning the majority shares of the public entity. The public "shell" is a vital aspect of reverse merger transactions which is a publicly listed company with no assets or liabilities. It gets the name "shell" because the only thing remaining from the current company is its corporate shell structure. 
ii) Tax saving is another allurement for such type of mergers. Section 72A of Income tax Act 1961 provides an attractive tax relief for amalgamation of sick companies with a healthy and profitable companies to take the advantage of carry forward of losses.

How tax laws defined reverse mergers

Section 72A of the Income tax, 1961 is meant to facilitate rejuvenation of sick industrial undertakings by merging with healthier industrial companies having incentive in the form of tax savings designed with the sole intention to benefit the general public through continued productive activity, increased employment avenues and generation of revenue. Sickness among industrial undertakings is a matter of grave national concern and section $72 \mathrm{~A}$ provides for reviving financially non viable business undertakings.

The section provides for an effective course to facilitate the amalgamation of sick industrial units with sound ones by providing incentives and removing impediments in the way of such amalgamation. To save the government from social costs in terms of loss of production, employment and uneconomical burden of taking over and running sick industrial units are some of the motivating factors for introducing section $72 \mathrm{~A}$.

Provisions of section $72 \mathrm{~A}$

1) Amalgamation should be between companies and none of them should be a firm of partners or sole proprietor.

2) The companies entering into amalgamation should be engaged in either industrial activity or shipping business, thus companies engaged in trading activities or services shall not be entitled for taxation benefits under section $72 \mathrm{~A}$.

3) After amalgamation the sick or financially unviable company shall survive and other income generating company shall extinct.

4) One of the merger partners should be financially unviable and have accumulated losses to qualify for the merger and the other merger partner should be profit earning so that tax relief to the maximum extent could be had.

5) Amalgamation should be in the public interest.

6) Accumulated loss should arise from Profits and gains from business or profession and not be loss under the heading Capital gains or speculation.

7) Merger must result into following benefits :

a) Carry forward of accumulated losses of the amalgamated company.

b) Carry forward of unabsorbed depreciation of the amalgamated company.

c) Accumulated loss would be allowed to carried forward for eight consecutive years.

8) For qualifying, carry forward of losses, the provisions of section 72 should have not been contravened.

9) Similarly for carry forward of unabsorbed depreciation the conditions of section 32 should not have been violated.

10) Specified authority has to be satisfied of the eligibility of the company for the relief under section 72 of the Income Tax Act. It is only on the recommendation of the specified authority that Central Government may allow the relief.

11) The company should make an application to a specified authority for requisite recommendation of the case to the Central Government for granting the relief.

\section{Prevalence of Reverse Merger in Indian Industries-}

Presently in India Reverse merger is still in its infancy stage, however slowly and steadily it is gathering its popularity in Indian corporate sector. Some good examples where reverse merger has taken place are :

1. In 2002, the board of directors of ICICI andICICI Bank approved the reverse merger of ICICI, ICICI Personal financial services limited and ICICI Capital services limited into ICICI Bank.

2. The Sajjan Jindal-controlled Jindal Iron and Steel company (JISCO) and its subsidiary, Jindal Vijaynagar steel (JVSL), are planning to consolidate their businesses to create a Rupees 4000 croreplus entity. As per the plan, the parent JISCO will be merged into JVSL in a reverse merger. (source: Business Standard October 21, 2010).

3. Merger of CORUS with TATA

4. Godrej soaps LTD.(GSL) with pre-merger turnover of RS.436.77 Crores and entered into scheme of reverse merger with loss making Gujarat innovative chemicals limited(GGICL) with pre-merger turnover of Rs 60 Crores.

\section{Conclusion-}

Reverse Mergers are far more popular in the US as there have been around 200 reverse mergers per year since 2004 and China has witnessed around 150 companies getting publicly listed through this route (source: Business Week). 
In India, there have been instances of reverse merger but, this as a method of listing and tax saving is yet to gain momentum here. However, if it can achieve serious scales in US and China, there is no reason that why it cannot pick up in India.

\section{References:}

[1]. Lars-Hendrik Roller and Johan Stennek 2000.- Efficiency Gains from Mergers.

[2]. Huizinga, Harry and Nicodeme, Gaeten Nicodeme 2003, Foreign Ownership and Corporate Income Taxation:

[3]. Richardson, Martin, 1999, Trade and competition policies.

[4]. Lockwood,B. 2000, Tax competition and Tax coordination under Destination and origin principles: A Synthesis

[5]. Barros, PedroP and Cabral, Luis,1994. Merger policy in open market 